\title{
Death Don't Have No Mercy: Cell Death Programs in Plant-Microbe Interactions
}

\author{
Jeffery L. Dangl, a,b,1 Robert A. Dietrich, ${ }^{a}$ and Michael H. Richberg ${ }^{a}$ \\ a Department of Biology, University of North Carolina, Chapel Hill, North Carolina 27599 \\ b Curriculum in Genetics and Molecular Biology, University of North Carolina, Chapel Hill, North Carolina 27599
}

\section{INTRODUCTION}

A nearly ubiquitous feature of plant-pathogen interactions is host cell death. In its most recognizable form, host cell death is manifested as the rapid collapse of tissue, termed the hypersensitive response (HR). This response accompanies "incompatible interactions" and leads to disease resistance. As detailed below, the HR is programmed genetically in the plant and is a consequence of new host transcription and translation (Dixon et al., 1994; Godiard et al., 1994). The HR is a correlative feature of many but not all incompatible interactions controlled by classic disease resistance $(R)$ genes (Dangl, 1995; Staskawicz et al., 1995; see also Bent, 1996, in this issue). A local HR is often associated with the onset of systemic acquired resistance (SAR; Chester, 1933; Enyedi et al., 1992; Ryals et al., 1994, 1996, in this issue) in distal plant tissues. In addition, sites of the HR are invariably focal points for transcriptional induction of plant defense genes in neighboring cells (Somssich et al., 1988; Schmelzer et al., 1989). Subsequent biosynthesis of protective secondary metabolites and cell wall buttressing around the HR site are also thought to contribute to overall pathogen containment. Signals derived from cells undergoing the HR apparently contribute significantly to the induction of defense gene transcription in adjacent cells. However, certain bacterial mutants unable to elicit an HR are still competent to trigger the transcription of defense genes that are normally induced during both incompatible and compatible interactions (Jakobek and Lindgren, 1993).

Whether the cell death that constitutes the HR actually causes disease resistance by depriving the incoming pathogen of nutrients or by releasing microbiocidal compounds from dying cells is unclear. Alternatively, the HR could be the consequence of a mechanism that is actually killing both host and microbe cells. In fact, recent evidence discussed below suggests that HR cell death is not required to stop pathogen growth in at least some cases (Century et al., 1995; Hammond-Kosack et al., 1996). If this separation of resistance per se and cell death is generalizable, can we glean insight from the mechanism by which host cells die that is relevant to the mechanism that kills or stops an invading pathogen?

\footnotetext{
1 To whom correspondence should be addressed.
}

Cell death is equally a feature of disease symptoms during compatible interactions. In many cases, cells are killed via the action of pathogen-derived toxins. In others, most notably compatible interactions with biotrophic fungi, cell death associated with disease symptoms is a very late feature of the disease course. Although not a major focus of this review, in at leasi one example, ethylene insensitivity leads to dramatically reduced symptom development (Bent et al., 1992), but the same lack of ethylene perception does not effect the onset of SAR (Lawton et al., 1994, 1995). Thus, the cell death associated with this example of disease (Pseudomonas syringae on Arabidopsis) is not required for triggering SAR. In contrast, many examples of necrosis induced by compatible pathogens do induce SAR (Jenns and Kuć, 1977; Cohen and Kuć, 1981; Kuć, 1987). Therefore, if the ability to induce SAR is used as a criterion, two cell death pathways are potentially engaged during compatible interactions. It is unknown whether the mechanism of cell death during the HR is the same as that invoked during cell death leading to disease symptoms. Examination of morphological characteristics associated with cell death suggests, as detailed below, that at least some steps are shared.

This review discusses these phenomena, with an emphasis on recent investigations aimed at genetic and biochemical dissection of the mechanisms underlying the HR. Key questions, many still unanswered, are as follows: Is the cell death in either case programmed genetically by plant cells (suicide), or is it entirely a consequence of pathogen-derived products killing plant cells (murder)? Is the HR a requirement for successful activation of resistance at and immediately surrounding the site of infection? Is cell death required for the onset of SAR? Are there fundamental mechanistic differences between $\mathrm{HR}$ cell death and disease symptoms, or are they two temporally different manifestations of the same death pathway? What is the role of reactive oxygen intermediates (ROI) in HR cell death? Finally, it is well established that programmed cell death (PCD) plays key roles in several aspects of normal plant development, as it does in normal animal development (Wyllie et al., 1980; Raff, 1992; Hengartner and Horvitz, 1994). This topic is included in recent reviews of cell death in plants (Greenberg and Sussex, 1996; Jones and Dangl, 1996) and so is only mentioned here insofar as particular developmentally observed cell deaths share features with the HR. 


\section{PARANOID PLANTS: THE GENETICS OF CELL DEATH}

Mutants that capriciously form patches of dead tissue in the absence of a pathogen exist in many plant species. These patches in some cases resemble those resulting from the HR and distinctly resemble disease symptoms caused by a particular pathogen in others. The phenotypes of these mutants led to the coining of the term "paranoid plants" because they behaved as if constantly under pathogen attack. These mutations are common in at least maize and Arabidopsis (Walbot et al., 1983; Greenberg and Ausubel, 1993; Dietrich et al., 1994; Greenberg et al., 1994; Johal et al., 1994a; Weyman et al., 1995). A key problem with mutants of this sort is to establish whether they define genes whose wild-type functions are involved in disease resistance. Their cell death phenotypes could equally be a consequence of perturbed metabolism or impaired signal exchange with neighboring cells; this is sufficient to initiate PCD in animals, in which one or more central monitors interpret intra- and extracellular signals. When these signals are absent or altered, the monitor(s) shunts the cell into a default suicide pathway. Thus, for an animal cell to survive, proliferate, and differentiate, it must continuously be reassured that it is doing the appropriate thing in the correct place. This "social control" of cell death in animal cells (Raff, 1992; Raff et al., 1993) may also operate in plant cells during either developmentally regulated PCD (R. Pennell, personal communication) or the HR.

Several cell death mutants express histochemical and molecular markers that are associated with resistance responses, and they also exhibit local and systemic resistance to a variety of pathogens that would ordinarily interact compatibly and cause disease (Dietrich et al., 1994; Greenberg et al., 1994; Jones, 1994). It has therefore been possible to set criteria separating the broad class of impaired cell death control mutants into those that define genes whose wild-type function affects the salicylic acid (SA)-dependent disease resistance pathway (see below, and Ryals et al., 1996, in this issue) and those that do not. Importantly, other mutants displaying dead cells, or other treatments that kill cells, do not engage the SAR pathway. Thus, the complete machinery necessary for triggering the cell death indicative of the HR is intrinsically programmed, and this program can lead to SAR. Collectively, these mutants offer the opportunity to decipher the signal transduction pathway of the HR. Ultimately, such mutants will help to address the key question of whether the programmed sacrifice of a limited region of cells halts pathogen proliferation or if lesion formation is merely collateral damage suffered attendant to the resistance mechanism.

\section{Initiation, Propagation, and Rogue $R$ Genes}

Bona fide HR lesions form specifically at the site of pathogen infection and end in a discrete boundary. In contrast, cell death mutants either stochastically form lesions of a determinate size at inappropriate locations (initiation class mutants) or are unable to constrain the extent of lesion expansion after it is initiated (propagation class mutants). The existence of initiation class mutants implies that an early step in the HR pathway is malfunctioning, possibly in signal transduction or in the signal receptor itself. Supporting this idea are at least two classes of lesion-mimic mutations that map to known $R$ loci (RP1 in maize and $m / 0$ in barley; see below). Because some cloned $R$ genes encode products containing kinase domains and others bear domains that putatively use trinucleotide binding as a signal switch (Dangl, 1995; Staskawicz et al., 1995; Boyés et al., 1996; see also Bent, 1996, in this issue), it is conceivable that mutations in these domains could lead to a constitutively signal-transducing phenotype (Pryor, 1987a, 1987b; Pryor and Ellis, 1993; Hu et al., 1996). Thus, " $R$ genes gone bad" could result in either determinate or propagative lesions, depending on the nature of subsequent signals in halting HR-like cell death.

Alternatively, and by analogy to animal cells as mentioned above, the default pathway of a metabolically injured plant cell may be a form of PCD. If so, then some initiation class mutants may lack negative regulators of HR formation that normally act as a phytological deadman's switch, preventing inappropriate flux through the HR pathway and thus stopping default PCD. Propagation class mutants are defective in their ability to limit lesion spread after it is initiated. These mutant phenotypes suggest that during the formation of a wild-type $\mathrm{HR}$ resulting from an incompatible reaction, signals emanate outward to neighboring cells and can trigger their death. Once the HR site involves a particular number of cells, it appears that a second control system inhibits its further spread. If this inhibiting mechanism is absent, any cell death accompanying the HR expands and can eventually consume the entire leaf.

Mutants of both initiation and propagation classes can occur naturally, can be isolated after mutagenesis, or can be generated by constitutive transgene expression. Many are developmentally regulated, and their phenotypes can be exacerbated by manipulation of hormone levels, light regime, or temperature. We detail below a selection of the rich material available in the general class of cell death control mutants, specifically propagation class mutants that define wild-type genes whose roles appear to define key negative regulatory steps in the control of the HR.

One of the earliest reported lesion mimics was derived from attempts to breed resistance to tomato leaf mold, Cladosporium fulvum, into a commercial tomato line (Langford, 1948). Small brownish lesions that form near the tips of the lower leaves on the plants subsequently enlarge to engulf the leaves and sometimes extend to the stem in a developmentally regulated fashion. Exposure to intense light enhances the extent of lesion formation, which may implicate ROI in the cell death process. Initial experiments suggested that necrosis seemed to be a result of the interplay between the ne locus and the C. fulvum resistance gene Cf-2. Recent results, however, suggest that it is not $\mathrm{Cf}-2$ but a dominant gene linked to it that interacts with ne to cause lesions (Dixon et al., 1996). Isola- 
tion of this second Cf-2-linked dominant gene may shed light not only on how NE functions but on how its function is tied to that of $C f-2$ in the generation of cell death during a normal resistance response.

Many well-studied lesion-mimic mutations have been isolated in maize and Arabidopsis. Of 32 different lesion mimics known in maize, 23 are dominant gain-of-function mutations, and most of these are initiation class mutants (Walbot et al., 1983; Johal et al., 1994a). This is the largest class of gain-offunction mutants found in maize, and their prevalence suggests two divergent possible hypotheses: either many dominant mutations can lead to metabolic perturbations that drive cells down a default PCD pathway, or many of these mutations are in response networks normally recruited to fend off pathogens. If the latter is true, it implies that a large number of input points can be activated in the disease resistance response pathway. This could, in turn, reflect a large number of $R$ genes whose gain-of-function phenotype could give rise to lesion mimics.

This possibility is illustrated by the fact that several alleles responsible for lesion mimics of both initiation and propagation classes map to the $R p 1$ gene locus, a complex $R$ locus that encodes resistance to the rust fungus Puccinia sorghi. The Rp1 locus exhibits a high frequency of unequal crossing over and gene conversion events (Hooker and Russell, 1962; Bennetzen et al., 1988; Sudupak et al., 1993). Plants expressing the rp1 lesion-mimic alleles can form many small lesions that do not become confluent in response to fungal infection, and some are resistant to infection by a large range of different rust fungi (Richter et al., 1995). A recent detailed appraisal of these mutants has defined three phenotypic subclasses ( $\mathrm{Hu}$ et al., 1996). These phenotypes lend further support to the ideas that at least some lesion mimics result from " $R$ genes gone bad" and that analysis of impaired cell death control pathways will inexorably dovetail with pathways controlling disease resistance.

Another maize mutant, lethal leaf spot 1 (//s1), is a Mutator $(M u)$ transposon-induced recessive propagation mutant that causes developmentally programmed and environmentally influenced lesions that mimic those formed on plants infected by Cochliobolus carbonum. Mechanical wounding of the plant tissue, such as puncturing it with a pin, also induces lesion formation (Ullstrup and Troyer, 1967; Johal et al., 1994b). L/s1 function is cell autonomous because revertant sectors do not die, despite being surrounded by dead tissue (Figure 1; Johal et al., 1994b). Lesion formation requires red light, implicating photorespiration and the action of ROI in the spread of cell death.

These observations suggest that a threshold level of tolerance to ROI is exceeded in //s1 mutant plants, especially when the tissue is actively photosynthetic, and that an excess of ROI may be the trigger initiating cell death (see below). The LLS1 gene product must function to promote removal of these cell death-promoting factors or else to inhibit their acting as a signal for PCD, although preliminary experiments involving quenchers of free radicals do not stop lesion formation (G. Johal
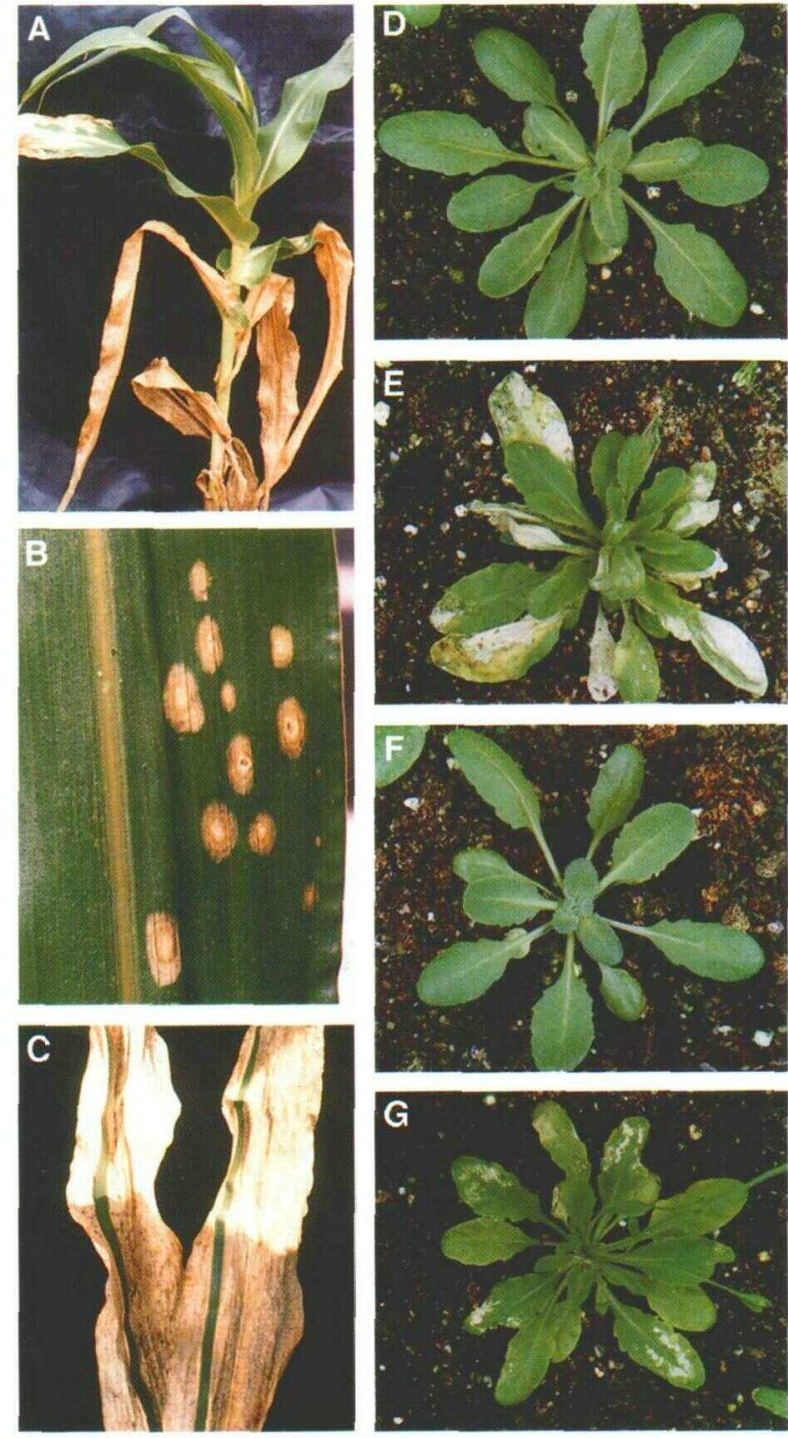

Figure 1. Variable Phenotypes of Cell Death Control Mutants.

(A) to (C) The maize l/s1 mutant. (A) Developmental control of lesion formation. Note the progression of lesions from the base of the plant upward. (B) Lesions initiated in the light by pinprick wounding. (C) Revertant sectors of IIs1. Sectors show the cell-autonomous nature of LLS1 function in limiting the progression of cell death.

(D) and (E) The Arabidopsis Isd1 mutant. (D) Growth in a permissive environment. (E) Growth in a nonpermissive environment. Lesions spread dramatically over a 3-day time course after shifting to nonpermissive conditions.

(F) and (G) The Arabidopsis /sd 3 mutation. (F) Growth in a permissive environment. (G) Growth in a nonpermissive environment. This mutation is also conditional, but lesions form more slowly over a 7- to 10-day time frame and are determinate in size.

Figures (A) to (C) courtesy of Guri Johal and John Gray (University of Missouri). 
and J. Gray, personal communication). Recently, a fragment of the LLS1 gene has been cloned after $M u$ transposon tagging. Preliminary DNA sequence analysis indicates that the IIs1 gene encodes a novel protein. A highly homologous expressed sequence tag exists in Arabidopsis (72\% amino acid identity over 100 residues), suggesting that the LLS1 encodes a cell death-controlling factor conserved between dicots and monocots (G. Johal and J. Gray, unpublished data).

In keeping with the number of mutant loci in maize that exhibit lesion-mimic phenotypes, several classes of Arabidopsis mutants also exhibit impaired cell death control. The lesions simulating disease resistance (/sd) class was identified based on its inappropriate formation of disease resistance-like lesions and its induction of local and systemic resistance to pathogen isolates virulent on the wild-type parent (Dietrich et al., 1994). The recessive /sd1 mutant forms propagation class lesions, and its wild-type product is apparently necessary to contain lesion size during the HR. Isd 1 forms lesions in response to inoculation with low levels of a wide variety of pathogens, and treatments with SA or other chemicals induce SAR. Lesions do not form in response to heat-killed bacteria, SA structural conformers that do not trigger SAR, and mechanical insult (thus, differentiating the /sd1 phenotype from maize IIs1). Recently, Jabs et al. (1996) have shown that the superoxide radical is a key signal molecule for both initiation and propagation of $/ s d t$ lesions (see below).

The accelerated cell death 1 (acd1) mutant also forms propagative lesions in response to challenges similar to those that induce lesions on /sd1. In addition, acd1 forms lesions in response to abiotic stresses, such as mechanical stress (like the maize /s1 mutant) and wounding during inoculation with $\mathrm{MgSO}_{4}$, that do not induce them on Isd1 (Greenberg et al., 1994). Developmental control of lesion onset in acd1 and /sd1 is also different, with newly emerging secondary rosette leaves under inductive conditions being lesion free in acd1 but lesioned in /sd1. It is highly unlikely that the acd mutant phenotypes result from defects in the production of antioxidant enzymes. No decrease in superoxide dismutase, catalase, or ascorbate peroxidase activities has been observed ( $\mathrm{J}$. Greenberg, personal communication). Because acd1 and /sd1 are nonallelic, there are at least two nonredundant wild-type functions in Arabidopsis that are required to halt the HR via negative regulation.

Propagation class mutants are by no means confined to Arabidopsis and maize. The Sekiguchi lesion of rice $(s /)$ is a naturally occurring, recessive propagation mutant (Kiyosawa, 1970; Marchetti et al., 1983). s/ lesions resemble responses to the ordinarily avirulent blast fungus Bipolaris oryzae. They are also triggered by avirulent isolates of Pyricularia oryzae but do not occur in response to virulent fungal isolates, supporting the idea that the s/ mutant is also impaired in the pathway that normally restricts a successful HR to cells at or near the infection site. The s/ mutant also forms lesions in response to applied chemicals, such as sodium hypochlorite, pentachlorphenol, and organophosphates. It is unknown whether these chemicals induce biological SAR. Do these s/- inducing chemicals mimic other messengers of HR signal transduction in rice or just kill the plant cells, which then triggers propagative cell death? In either scenario, the s/mutation should be characterized further in the context of the maize and Arabidopsis mutants discussed above. It would be of interest to map s/ to determine if, like the maize Rp1 alleles, it represents a mutation in a specific rice blast $R$ gene.

The mlo gene is unique among barley $R$ genes in that it confers resistance to all known races of the fungus responsible for powdery mildew, Erysiphe graminis, but does not affect susceptibility to non-Erysiphe fungi (Wolter et al., 1993). The function of the wild-type Mlo allele is unknown, but mutant $m / o$ alleles result in thickening and apposition of cell wall material at the location of attempted penetration by fungal hyphae. Thus, wild-type Mlo presumably acts to downregulate genes directing apposition formation. Cell type-specific spontaneous cell wall appositions can occur in mlo plants grown in the absence of pathogen. These spontaneous cell wall thickenings are similar in chemical composition, structure, and tissue localization to appositions triggered by infection and may act as a physical barrier to pathogen attack (see Knogge, 1996, in this issue).

Although apposition formation in response to fungal hyphae does not result in cell death, lesions can appear on mlo plants at low temperatures in the absence of pathogen. The size and severity of these lesions can depend on the genetic background and the mlo allele, suggesting that an interplay between the Mlo gene product and a variety of other cellular factors usually determine the extent of apposition formation.

Because formation of cell wall appositions at the site of haustorial penetration is a fundamental mechanism of m/omediated disease resistance, understanding the factors that control their formation is critical to understanding this modification of a normal disease resistance mechanism. The recent characterization of mutants that negate both mlo-mediated resistance and apposition formation begins this dissection (Freialdenhoven et al., 1996). Interestingly, although the mlo mutation can cause lesion formation, it does not appear to trigger resistance to another barley leaf pathogen and thus does not condition a general activation of defense mechanisms (Freialdenhoven et al., 1996).

Cell death phenotypes are not limited to foliar tissues, as evidenced by the soybean $m$ (root necrosis) mutant. Lesionpositive roots are partially resistant to an isolate of fungus that is ordinarily pathogenic on the parental genotype. They also exhibit the induction of defense gene transcription and the subsequent accumulation of the phytoalexin glyceollin (Kosslak et al., 1996). No phenotype is seen in the foliar sections of these plants. This is distinct from the /sd1 and $/ / s 1$ mutant phenotypes, of which the former affects a variety of tissues, including floral organs (R.A. Dietrich, unpublished data). Thus, it may be that the diversity of foliar cell death phenotypes and the variety of developmental and environmental control over their onset and severity reflect a set of cell death control pathways. Whether this variety represents interplay between developmentally cued and pathogen-invoked $P C D$ remains to be seen. 


\section{SERENDIPITOUS CELL DEATH: TRANSGENICS}

Several transgenic plant lines express altered cell death control phenotypes. Although some of these phenotypes likely result from metabolic perturbation leading to cell death rather than misregulation of the pathogen response pathways, we examine in detail two examples of cell death generated by transgene expression that seem most easily reconciled with a role for the affected pathway in disease resistance. Other examples are described in Table 1.

Transgenic tobacco plants expressing the Halobacterium halobium light-driven proton pump bacterio-opsin exhibit lesion formation in the absence of pathogen as well as resistance to infection by fungal and bacterial aggressors (Mittler et al., 1995). Constitutive expression of this transgene resulted in a dominant initiation class mutant. Conversely, tobacco plants transformed with a bacterio-opsin construct containing a single

\begin{tabular}{|c|c|c|c|c|c|c|}
\hline Gene & Source & Wild-Type Function & Type of Cell Death & Resistance/Defense & Comments & Reference \\
\hline \multicolumn{7}{|l|}{ Pathogen genes } \\
\hline Avr9 peptide & C. fulvum & $\begin{array}{l}\text { Unknown Avr } \\
\text { determinant }\end{array}$ & $\begin{array}{l}\text { Catastrophic seedling } \\
\text { lethality at day } 13\end{array}$ & $\begin{array}{l}\text { Not tested in } \\
\text { tomato }\end{array}$ & Requires Cf-9 & $\begin{array}{l}\text { Hammond- } \\
\text { Kosack et al. } \\
\text { (1994) }\end{array}$ \\
\hline TMV CPa & TMV & $\begin{array}{l}\text { Coat protein Avr } \\
\text { determinant }\end{array}$ & Lesions, chlorosis & Not tested & $\begin{array}{l}\text { Requires } R \\
\text { gene } N^{\prime} \text { from } \\
\text { Nicotiana } \\
\text { sylvestris }\end{array}$ & $\begin{array}{l}\text { Culver and } \\
\text { Dawson } \\
\text { (1991) }\end{array}$ \\
\hline $\mathrm{CaMV}^{\mathrm{b}} \mathrm{gVI}$ & CaMV & $\begin{array}{l}\text { CaMV inclusion } \\
\text { body matrix } \\
\text { protein }\end{array}$ & Lesions, stunting & $\mathrm{PR}^{c}$ genes on & $\begin{array}{l}\text { Temperature } \\
\text { sensitive }\end{array}$ & $\begin{array}{l}\text { Takahashi et } \\
\text { al. (1989) }\end{array}$ \\
\hline \multicolumn{7}{|c|}{ Plant and other genes } \\
\hline rgp1 & Rice & $\begin{array}{l}\text { Small GTP. } \\
\text { binding } \\
\text { protein }\end{array}$ & None noted & TMV resistance & $\begin{array}{l}\text { Compromised } \\
\text { by use of } R_{0} \\
\text { plants }\end{array}$ & $\begin{array}{l}\text { Sano et al. } \\
\quad(1994)\end{array}$ \\
\hline $\begin{array}{l}\text { Poly-ubiquitin } \\
\text { dominant } \\
\text { variant }\end{array}$ & Plant & $\begin{array}{l}\text { Protein } \\
\quad \text { degradation }\end{array}$ & $\begin{array}{l}\text { Punctate, } \\
\text { determinate }\end{array}$ & $\begin{array}{l}\text { TMV resistance, } \\
\text { altered lesions }\end{array}$ & $\begin{array}{l}\mathrm{N} \text {-independent } \\
\text { PR-1 } \\
\text { activation } \\
\text { after TMV } \\
\text { infection }\end{array}$ & $\begin{array}{l}\text { Becker et al. } \\
\text { (1993) }\end{array}$ \\
\hline Invertase & Yeast & $\begin{array}{l}\text { Hexose } \\
\text { transport }\end{array}$ & $\begin{array}{l}\text { Autofluorescence, } \\
\text { severe necroses }\end{array}$ & $\begin{array}{l}\text { Enhanced local } \\
\text { necrosis in } \\
\text { potato virus } Y \\
\text { infections, } \\
\text { systemic } \\
\text { resistance }\end{array}$ & $\begin{array}{l}\text { SA elevated, PR } \\
\text { genes and } \\
\text { phenylalanine- } \\
\text { ammonia } \\
\text { lyase on, } \\
\text { requires } \\
\text { vacuolar or } \\
\text { cell wall } \\
\text { invertase }\end{array}$ & $\begin{array}{l}\text { Herbers et al. } \\
(1996)\end{array}$ \\
\hline Cholera toxin & $\begin{array}{l}\text { Vibrio } \\
\quad \text { cholerae }\end{array}$ & $\begin{array}{l}\text { Blocks GTPase, } \\
\text { signal } \\
\text { constitutive }\end{array}$ & $\begin{array}{l}\text { Age-dependent, callose } \\
\text { minus }\end{array}$ & $\begin{array}{l}\text { Elevated SA, } \\
\text { PR genes on, } \\
P . \text { tabaci } \\
\text { resistant }\end{array}$ & $\begin{array}{l}\text { Local effect, not } \\
\text { graft } \\
\text { transmitted }\end{array}$ & $\begin{array}{l}\text { Beffa et al. } \\
\quad(1995)\end{array}$ \\
\hline $\begin{array}{l}\text { Opsin proton } \\
\text { pump }\end{array}$ & $\begin{array}{l}\text { Halobacterium } \\
\text { halobium }\end{array}$ & Proton pump & $\begin{array}{l}\text { HR-like on stems, } \\
\text { leaves }\end{array}$ & $\begin{array}{l}\text { Elevated SA, } \\
\text { PR genes on } \\
\text { TMV resistant }\end{array}$ & $\begin{array}{l}\text { Temperature } \\
\text { sensitive as } \\
N\end{array}$ & $\begin{array}{l}\text { Mittler and } \\
\text { Lam (1995) }\end{array}$ \\
\hline Barnase & $\begin{array}{l}\text { Bacillus } \\
\text { amylolique- } \\
\text { faciens }\end{array}$ & RNAse & $\begin{array}{l}\text { Pathogen induced via } \\
\text { pathogen-induced } \\
\text { promoter }\end{array}$ & $\begin{array}{l}\text { Reduced } \\
\text { Phytophthora } \\
\text { infestans } \\
\text { sporulation }\end{array}$ & $\begin{array}{l}\text { Ethylene } \\
\text { inducible, } \\
\text { Barstar } \\
\text { moderated } \\
\text { cell death }\end{array}$ & $\begin{array}{l}\text { Strittmatter et } \\
\text { al. (1995) }\end{array}$ \\
\hline
\end{tabular}

a $\mathrm{CP}$, coat protein.

- CaMV, cauliflower mosaic virus.

c PR, pathogenesis related. 
amino acid change that occludes the putative proton channel formed no lesions. Therefore, this cell death phenotype appears to be a direct result of channel activity by the bacterio-opsin protein. Lesion formation in this example exhibits temperature sensitivity in a manner that parallels that of the tobacco N R gene: growth at $30^{\circ} \mathrm{C}$ inhibits lesion formation, but shifting the plants to a cooler temperature allows systemic lesion formation. This temperature-sensitive cell death suggests that the bacterio-opsin protein may be activating a downstream portion of the pathway that is also induced by the $\mathrm{N}$ gene. Because plasma membrane $\mathrm{H}^{+}$-ATPases appear to play a role in some plant defense responses (Vera-Estrella et al., 1994; Xing et al., 1996; see Knogge, 1996, in this issue), and because $\mathrm{H}^{+} / \mathrm{K}^{+}$exchange is a very early event correlated with incompatible interactions (see below), it is likely that this particular transgene expression-induced cell death is reflective of events occurring during the normal HR.

Manipulations of the ubiquitin-regulated protein degradation pathway can also result in lesion-mimic phenotypes (Becker et al., 1993). Transformation of tobacco with a modified ubiquitin that is unable to polymerize, an essential step in the ubiquitin degradation pathway, causes initiation-type lesions to form. When challenged with tobacco mosaic virus (TMV), transgenic plants carrying $N$ form fewer but darker lesions than do control untransformed $N$ plants. TMV infection of transgenic tobacco not expressing $N$ resulted in expression of high levels of a particular defense gene, pathogenesisrelated gene 1 (PR-1). This gene is a good marker for the onset of SAR (see Ryals et al., 1996, in this issue) and is not expressed in untransformed wild-type plants. Intriguingly, only low levels of PR-1 are present in spontaneously lesion-forming axenically grown plants. This phenotype is unlike the other cell death control mutants in which plants with lesions express high levels of PR-1 mRNA. Because large net changes in cellular metabolism accompany pathogen challenge, it is conceivable that alterations in ubiquitin-dependent protein metabolism could be tightly coupled with normal disease resistance mechanisms.

\section{THE REAPER'S POINTED FINGER: THE UTILITY OF DIRECTED DEATH}

A key question in all plant-pathogen interactions is: How is the pathogen avirulence (Avr) gene signal specifically delivered to the $R$ gene product? Transgenic experiments assessing the expression of an intracellular Avr gene (encoding the TMV coat protein) led to $N^{\prime}$-dependent cell death in tobacco (Culver and Dawson, 1991). The C. fulvum Avr9 peptide, which is sufficient to cause Cf-9-mediated resistance reactions (Van Kan et al., 1991; Van den Ackerveken et al., 1992), was expressed extracellularly in tomato plants by using a similar strategy (Hammond-Kosack et al., 1994). When these plants were crossed with Cf-9 tomato plants, hybrid seedlings died 13 days after germination. The permissive phase of the Avr9-Cf-9 interaction is potentially a function of developmental regulation of either promoter used in these experiments, but it does allow use of this and similar systems for further cell biological and genetic manipulation.

A different strategy is also being employed to engineer cell death at a site of pathogen infection. For example, a pathogeninduced promoter can be used to drive the expression of a toxin or degradative enzyme (RNase was used by Strittmatter et al. [1995]). When the promoter is triggered by pathogen infection, host cells die, ostensibly halting further pathogen growth. It will be of interest to test plants expressing engineered cell death systems for SAR. Important considerations in these strategies are tight pathogen-dependent expression of the promoter used and limiting the collateral damage to healthy, uninfected plant tissue.

\section{UNDOING DEATH: GENETIC EXPLOITATION OF CELL DEATH CONTROL MUTANTS}

A variety of cell death-impaired mutants, introduced above, are being used to help elucidate the mechanism and signal transduction for disease resistance and the HR, as outlined in Figure 2. In combination with double-mutant analyses using plants that enzymatically degrade SA via the expression of salicylate hydroxylase (encoded by the nahG gene; Gaffney et al., 1993; Delaney et al., 1994), it has been possible to place the Arabidopsis cell death mutants into the SA-dependent disease resistance pathway (Figure 2). Experiments using both Isd6 (Weyman et al., 1995) and Isd1 (U. Neuenschwander, R.A. Dietrich, J.A. Ryals, and J.L. Dangl, unpublished data) provide evidence for an amplification loop in the cell death signaling pathway. In combination with nahG, both are lesion minus, suggesting that SA accumulation is required for cell death in these two mutants. However, application of another chemical inducer of SAR, 2,6-dichloroisonicotinic acid, triggers the formation of typical punctate isd6 lesions and the spreading $/ s d 1$ lesions. Because it is thought that 2,6dichloroisonicotinic acid acts at the same point as or downstream of SA in this pathway (Delaney et al., 1995), one conclusion is that these mutants define steps in a feedback loop operating to interpret SA-dependent signals. These genetic results are consistent with other results implicating a feedback role for SA during the defense response (Kauss et al., 1992; Kauss and Jeblick, 1995; Mauch-Mani and Slusarenko, 1996; Mur et al., 1996; see also Ryals et al., 1996, in this issue). It will also be informative to combine the cell death control mutants with other mutants required for $R$ gene function, such as ndr (Century et al., 1995), whose position in the scheme shown in Figure 2 is tentative.

Along with traditional mapping and cloning techniques to identify the genes and proteins responsible for cell death control, seed from lesion-mimic plants can be mutagenized and examined for phenotypic revertants. The absence of lesions 


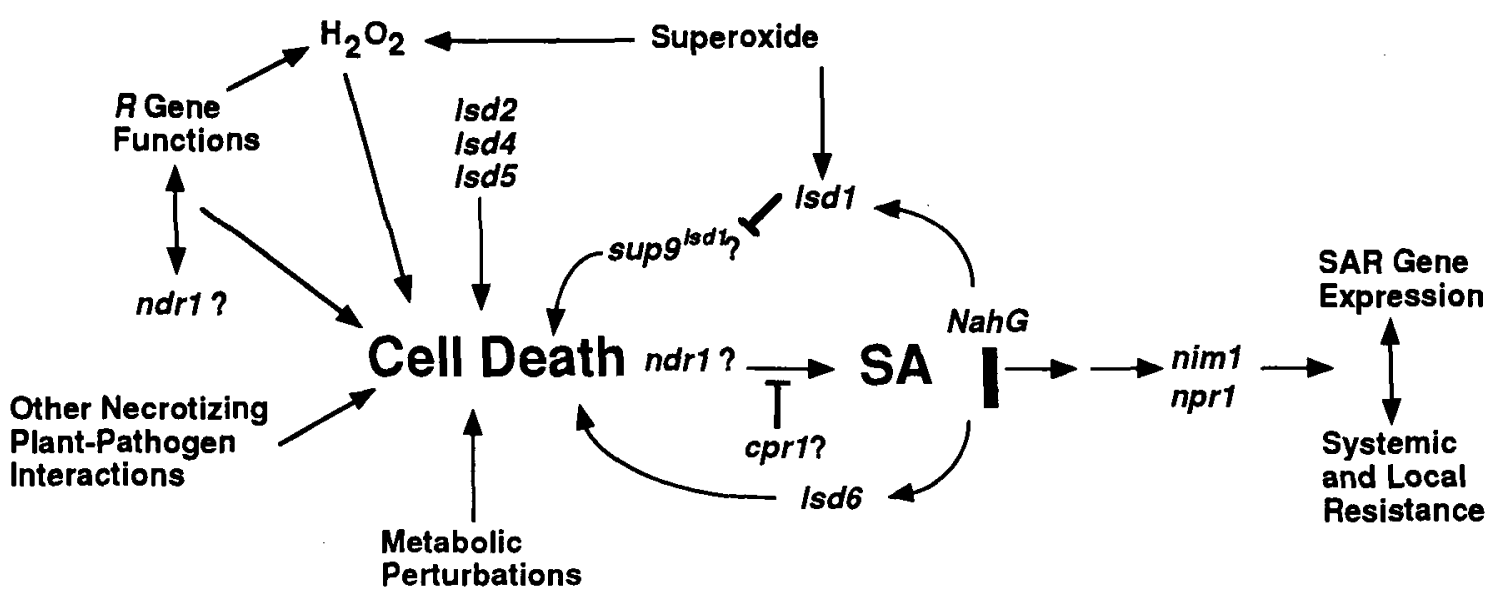

Figure 2. Tentative Cell Death Circuitry in Disease Resistance in Arabidopsis.

Many inputs, detailed in the text, lead to cell death. Cell death can result in the accumulation of SA, which in turn leads to the activation of downstream defense pathways that culminate in local and systemic resistance. SA accumulation is blocked by expression of the nahG gene. Signals depicted feeding into cell death could be in one or more linear pathways rather than independent inputs, as shown here. Question marks denote hypothetical positioning of various mutations. Arrows imply activation steps; blunt symbols imply negative regulatory roles for the wild-type products of LSD1 and CPR1. Double-mutant analysis of $I s d 6$ and $/ s d 1$ (see the text) provides genetic evidence for an amplification loop involved in determining the extent of cell death. Mutants noted here are from Bowling et al. (1994), Cao et al. (1994), Delaney et al. (1994, 1995), Dietrich et al. (1994), and Century et al. (1995). Note that the isd suppressors will be called Phoenix (phx) after the mythological bird that arises from

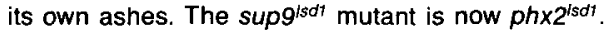

is an easily screened marker, especially for propagation class mutants such as $/ s d 1$ in Arabidopsis and //s1 in maize and earlyonset initiation class mutants such as /sd5 that can all be conditionally lethal. Such a screen can uncover extragenic suppressors of the original mutation, thus revealing other parts of the cell death signal transduction pathway. Also intriguing are the possibilities that suppressors of one /sd phenotype could suppress other cell death control mutations and/or exhibit altered interactions with pathogens.

Loci that suppress multiple cell death control mutations must define key steps in common pathways leading to cell death. For example, at least one of seven independent suppressors of the Arabidopsis $1 s d 5$ mutant also suppress $1 s d 4$ and, partially, Isd6 (J.-B. Morel, M. Hunt, J.A. Ryals, and J.L. Dangl, unpublished data). Both $/ s d 4$ and $/ s d 6$, as well as $/ s d 5$, are initiation class mutants, but they affect different cell types, have very different phenotypes, and fit into different steps in the pathway diagrammed in Figure 2. At least four of the $/ s d 5$ suppressors are also compromised in their response to pathogens (J.-B. Morel and J.L. Dangl, unpublished data), validating the usefulness of this approach in unraveling the HR and disease resistance pathways. In contrast, one extragenic recessive /sd1 suppressor (of the $\sim 12$ we have isolated) reverts all facets of the Isd 1 syndrome to the wild type (Jabs et al., 1996). Thus, this suppressor, called $p h \times 21^{1 / s^{17}}$, defines a gene whose wildtype function is inhibited by $\angle S D 1$ and that is probably acting positively to increase signal into the cell death pathway (see Figure 2). One prediction prompted by these findings is that this suppressor should not suppress "upstream" cell death mu- tants such as $/ s d 2$ and /sd4. Additionally, SA potentiation of signaling (Kauss et al., 1992; Kauss and Jeblick, 1995; MauchMani and Slusarenko, 1996; Mur et al., 1996) should also be diminished.

\section{DEATH'S ELIXIR: REACTIVE OXYGEN INTERMEDIATES AND THE HR}

Increasing biochemical and genetic evidence points to the generation of $\mathrm{ROI}$ as a key trigger in the PCD accompanying the HR (see Mehdy, 1994; Baker and Orlandi, 1995; Low and Merida, 1996, for detailed reviews). For the purpose of this article, the key to the emerging time line of signal transduction events that culminate in the HR is that cell death begins after $\mathrm{ROI}$ production, leading to the notion that the latter causes the former, either directly or indirectly. Does the ROI formed in this oxidative burst directly kill either host or pathogen cells or both? Can the ROI thus formed additionally act as signal molecules to trigger an independent cell death pathway and defense gene transcription? For example, hydrogen peroxide $\left(\mathrm{H}_{2} \mathrm{O}_{2}\right)$ produced during the $\mathrm{HR}$ has been demonstrated to trigger transcription of antioxidant genes in adjacent tissue (Levine et al., 1994; Inzé and Van Montagu, 1995). This result suggests that low levels of ROI could also be a signal that turns on the host's endogenous cellular protectants, which may in turn limit the size of a growing lesion. ROI at levels produced after inoculation with incompatible pathogens (Peng and Kuć, 
1992) can also kill microbes in vitro, and plant cells can be killed by high levels of externally generated $\mathrm{H}_{2} \mathrm{O}_{2}$ (Levine et al., 1994). Additionally, the ROI that accumulate specifically during incompatible interactions could cause oxidative crosslinking and strengthening of cell walls (Bradley et al., 1992; Brisson et al., 1994). Finally, one clear example exists in which the in vivo expression of an $\mathrm{H}_{2} \mathrm{O}_{2}$-generating system in the apoplast of potato tubers led to much-improved levels of resistance to Erwinia and Phytophthora infestans infections (Wu et al., 1995). This study did not address whether $\mathrm{H}_{2} \mathrm{O}_{2}$ was directly responsible for halting the pathogen or functioned as a signaling molecule to generally enhance defense responses.

\section{A Sum of Signals}

As schematically summarized in Figure 3 , current models suggest that the engagement of pathogen recognition pathways during both $R$ gene-mediated and nonhost resistance leads to a series of very rapid signal transduction events, which in turn lead to ROI production and perception, defense gene activation, phytoalexin biosynthesis, and the induction of the

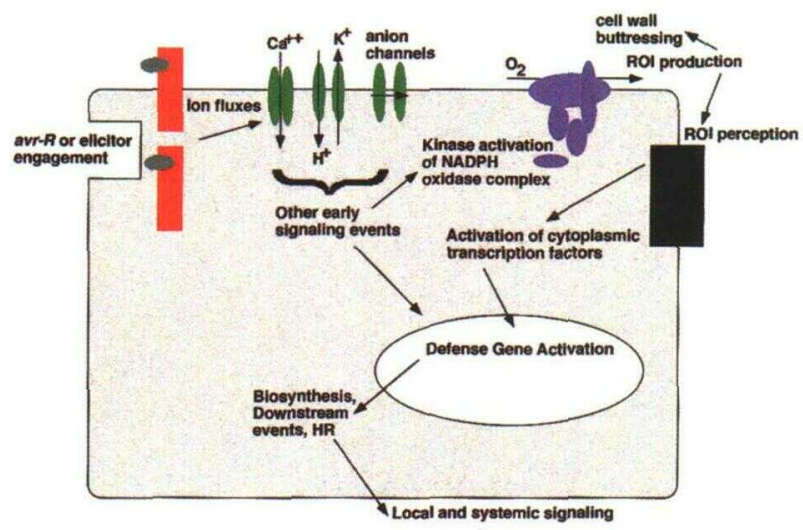

Figure 3. Early Signaling Events in the Activation of Cell Death and Disease Resistance.

Extra- or intracellular perception of Avr-dependent or elicitor signals by $R$ gene products (gray spheres and red blocks, respectively) results in $\mathrm{Ca}^{2+}$ influx; $\mathrm{K}^{+} / \mathrm{H}^{+}$exchange, leading to acidification of the cell; anion channel opening (green); and activation of the NADPH-oxidase complex (purple), leading to ROI production. Additional early signaling can precede the oxidative burst and can include activation of kinases, phosphatases, phospholipases, lipid peroxidation (see the text), and cytoplasmic rearrangement (Freytag et al., 1994). ROI can have immediate effects on cell wall strengthening via peroxidase action and can be perceived (black box) by the cell to engender intracellular responses (see the text). Subsequent to the activation of defense gene transcription are other downstream effector events that include SA biosynthesis, biosynthesis of phytoalexins and pathogenesis-related proteins, the HR, and systemic signaling. This diagram is generated from diverse experimental systems, and it is not intended that each step shown is operative in each system. Relative timing of events has been established in only a few systems, as detailed in the text. remainder of the defense battery (see Hammond-Kosack and Jones, 1996, in this issue). We introduce a few details only insofar as they are relevant to the role of ROI in the HR.

Among the earliest events (within 10 mins; see Nürnberger et al., 1994) are the influx of $\mathrm{Ca}^{2+}$, the exchange of $\mathrm{H}^{+}$for $\mathrm{K}^{+}$ inside the cell (leading to acidification of the cell), and the opening of anion channels, particularly chloride ion channels. A requirement for calcium influx for subsequent signaling events has been demonstrated in at least some systems (Schwacke and Hager, 1992; He et al., 1993; Nürnberger et al., 1994; Hahlbrock et al., 1995; Tavernier et al., 1995). Anion channel blockers prevent activation of the oxidative burst and defense gene transcription in parsley cells treated with fungal elicitor (T. Jabs and D. Scheel, personal communication). Moreover, inhibition of the elicitor-dependent oxidative burst prevents defense gene activation but not ion fluxes, placing ROI production downstream of ion flux in this system. Other activator-inhibitor studies, largely performed on cultured cells, have implicated a variety of signaling molecules (Figure 3), including G proteins, kinases and phosphatases, and phospholipases, in ROI generation. Other than the Pto and Pti kinases (Martin et al., 1993; Zhou et al., 1995; Boyes et al., 1996), a causal requirement for these classes of molecule in disease resistance has not been demonstrated (Dixon et al., 1994; Low and Merida, 1996). That preexisting transcription factors can coordinate early resistance responses is derived from experiments demonstrating a lack of cycloheximide inhibition of PR-1 transcription (Uknes et al., 1993; Qin et al., 1994).

$\mathrm{Ca}^{2+}$ influx caused by external $\mathrm{H}_{2} \mathrm{O}_{2}$ application ( $8 \mathrm{mM}$; see below), acting through a kinase and proteinase, is necessary and sufficient to trigger HR-like cell death in soybean cell cultures (Levine et al., 1994, 1996). This result either places the oxidative burst upstream of ion flux, a result inconsistent with the relative time line generated in the elicitor-parsley cell system described above, or suggests alternative or feedback pathways involved in $\mathrm{Ca}^{2+}$-dependent signaling of downstream events.

Recently, purified C. fulvum Avr-encoded peptide elicitors were used to establish a temporal order of signaling events in tomato leaves during $R$ gene-dependent reactions (Hammond-Kosack et al., 1996; May et al., 1996). These results showed that $R$ gene-dependent signaling systems can be both kinetically and qualitatively different from one another but that in general conform to the model in Figure 3 (see also Hammond-Kosack and Jones, 1996, in this issue). A critical finding is that in this system, at least half of the cell death triggered in Cf-9-dependent interactions with the Avr9 peptide elicitor are inhibited in very high relative humidity, but resistance to the fungus still occurs.

\section{The Burst That Refreshes}

The oxidative burst was first reported (Doke, 1983, 1985; Doke and Ohashi, 1988) to result in accumulation of superoxide, which is neither particularly stable nor particularly toxic and 
cannot cross cell membranes (Halliwell and Gutteridge, 1989). Superoxide can be dismutated to the more toxic $\mathrm{H}_{2} \mathrm{O}_{2}$ (which can cross membranes) and can undergo other conversions to even more noxious ROI (detailed in Hammond-Kosack and Jones, 1996, in this issue).

It is probable that the production of ROI in plants is mediated by a plasma membrane-anchored NADPH-oxidase system analogous to that used by mammalian neutrophils to kill intracellular pathogens (Segal and Abo, 1993; Low and Merida, 1996). The magnitude of the HR-associated oxidative burst is essentially the same as that shown to be sufficient for direct pathogen killing by neutrophils. An inhibitor of the mammalian NADPH-oxidase system in mammals, diphenylene iodonium, inhibits both the ROI burst and downstream signaling events in plants. Moreover, antisera to key mammalian protein components in this system cross-react with appropriately sized plant proteins (Dwyer et al., 1995; Tenhaken et al., 1995). At least two functionally separable NADPH oxidases exist in rose cell plasma membranes (Auh and Murphy, 1995; Murphy and Auh, 1996), and their engagement leads to the activation of defense responses in a diphenylene iodonium-inhibitable manner. Recently, rice genes homologous to one of the five key protein components of the neutrophil NADPH-oxidase complex have been isolated (Groom et al., 1996).

In response to $P$. syringae inoculation of both leaves and cultured cells, an immediate Avr- $R$ gene-independent oxidative burst is followed by a trough and a second sustained Avr- $R$ gene-specific oxidative burst of $\sim 10$ to $100 \mu \mathrm{M} \mathrm{H}_{2} \mathrm{O}_{2}$, peaking between 2 and $5 \mathrm{hr}$ after inoculation (Mehdy, 1994; Baker and Orlandi, 1995; Low and Merida, 1996). In systems using purified elicitors (Baker et al.; 1993; Legendre et al., 1993; Levine et al., 1994; Nürnberger et al., 1994), this biphasic oxidative burst is often replaced by a rapid increase in ROI production. The initial oxidative burst may be due to low levels of activated NADPH oxidase already present in the cell, with prolonged ROI production being a consequence of the activation and recruitment of the NADPH-oxidase components to the plasma membrane. The lag time required for Avr-specific ROI production parallels the lag required for induction in plants of the hypersensitive response and pathogenicity (hrp)-Avr gene regulons which give rise to Avr-dependent signals (see Alfano and Collmer, 1996, in this issue). All of the published experiments based on these systems have used bacteria grown on rich media, and it has been established that there is a lag of 2 to $3 \mathrm{hr}$ after transfer, either to plants or to minimal media supplemented with fructose or sucrose, before the onset of hrp and Avr gene expression in P. syringae (Huynh et al., 1989). Thus, the first Avr-nonspecific phase of ROI production may be due to other pathogen elicitors that are not regulated in an hrp-dependent manner.

Both the sustained oxidative burst triggered by a specific Avr- $R$ gene-determined incompatible interaction and high levels of exogenous $\mathrm{H}_{2} \mathrm{O}_{2}$ (2 to $10 \mathrm{mM}$ ) killed soybean cells, and the dying cells exhibited a particular set of morphological features that are discussed below (Levine et al., 1994). Because of the very rapid decay of $\mathrm{H}_{2} \mathrm{O}_{2}$ in cell culture, these authors argue that application of millimolar amounts of $\mathrm{H}_{2} \mathrm{O}_{2}$ delivers the same effective dose to cells as that normally evolved during incompatible interactions with bacteria. Moreover, the similarity of dying cell morphologies is used to argue that death by bacteria and death by $\mathrm{H}_{2} \mathrm{O}_{2}$ are equivalent in this system. However, this conclusion is challenged by findings that ROI levels similar to those observed in the $P$. syringae-soybean cell system are insufficient to kill cultured parsley cells ( $\sim 30$ $\mu \mathrm{M}$; T. Jabs and D. Scheel, personal communication). In addition, a $P$. syringae mutant that is unable to trigger the HR in tobacco leaves still causes normal levels of ROI to be formed in tobacco cell cultures (Glazener et al., 1996). In this example, $\mathrm{H}_{2} \mathrm{O}_{2}$ levels of $\sim 10 \mu \mathrm{M}$ are insufficient to cause the HR. Part of the confusion in this debate will be rectified when measurements of ROI in leaves undergoing usual plant-pathogen interactions can be carefully measured. This is critical, because it is known that ROI toxicity and half-life are very much influenced by the local physiological environment (Halliwell and Gutteridge, 1989).

Levine et al. $(1994,1996)$ also demonstrated that low levels of $\mathrm{H}_{2} \mathrm{O}_{2}$ can act over distances of a few cells to induce glutathione S-transferase (an antioxidant) gene transcription. This transcriptional activation is not inhibited by $\mathrm{Ca}^{2+}$ channel blockers and is thus separable from the $\mathrm{Ca}^{2+}$-dependent cell death triggered in this system. Downstream effects of peroxide signaling additionally include increases in SA-biosynthetic enzymes (Léon et al., 1995), transcription of PR genes (Bi et al., 1995; Neuenschwander et al., 1995), and potentially, the generation of lipid peroxides via the action of the hydroxyl radical (Croft et al., 1993).

Other ROI certainly will be shown to have other signaling roles in HR cell death. For example, we have recently demonstrated that superoxide is a key regulator of induction of the spreading cell death associated with the /sd1 mutation (Jabs et al. 1996). Superoxide, and not $\mathrm{H}_{2} \mathrm{O}_{2}$, is both necessary and sufficient for initiation and spread of lesions. If one accepts the position of /sd1 in the regulatory circuit shown in Figure 2 , then these new data suggest that the wild-type LSD1 protein is a key regulator of feedback flux through the cell death pathway and that it monitors a signal whose strength is dependent on superoxide.

\section{THE FACES OF DEATH: THE MORPHOLOGY OF DYING CELLS DURING THE HR AND ONSET OF DISEASE SYMPTOMS}

Several recent experiments have explored the parallels between cell death associated with the HR and disease symptoms and $\mathrm{PCD}$ in animal systems. In particular, comparisons with the subset of animal PCD known as apoptosis are emerging. Apoptosis occurs in animals during normal development and also in response to certain pathogens. It is characterized in a variety of animal cells by an ordered process leading to the 
breakdown of the dying cell. Cells undergoing apoptosis shrink, and although plasma membrane and organellar integrity are retained, the nuclear DNA condenses and is cleaved into fragments of $\sim 50 \mathrm{~kb}$. Nuclear DNA is often (but not always) further cleaved by endogenous $\mathrm{Ca}^{2+}$-dependent endonucleases into oligonucleosomal-sized fragments. These can be visualized on a gel as a ladder of DNA with fragments of multiples of $\sim 180$ bp that are diagnostic for some but not all forms of apoptosis. The fragmentation of the nuclear DNA results in the breakdown of chromatin structure. Meanwhile, the nucleus breaks up into apoptotic bodies, small membrane-bound structures containing the fragmented DNA. These bodies migrate to the margin of the cell and are taken up by adjacent cells. This series of events contrasts with necrotic cell death in animals, which is characterized by membrane breakdown and permeability, swelling of the organelles, and finally disintegration of the cell.

Recent studies have examined plant cells undergoing cell death in a variety of conditions (infections and developmentally cued cell death) to determine whether the process resembles apoptosis or necrosis as seen in animals (reviewed in Hengartner and Horvitz, 1994; Vaux et al., 1994; Korsmeyer, 1995; Stellar, 1995; Wyllie, 1995). These results indicate that several features of apoptosis may occur in at least some plant responses to pathogens. DNA fragmentation, as detected in situ by an assay that detects free $3^{\prime}-\mathrm{OH}$ groups on the broken DNA, has been demonstrated in TMV-inoculated tobacco and in the lesion mimic generated by overexpression of the bacterial proton pump (Mittler and Lam, 1995). Although this assay indicates the presence of $3^{\prime}-\mathrm{OH}$ groups, it does not necessarily imply the ordered DNA fragmentation characteristic of animal apoptosis (Collins et al., 1992). In a more recent report, fragmentation into $\sim 50-\mathrm{kb}$ fragments was reported in TMV-induced HR in tobacco. However, in the same study, similar-sized DNA fragments were detected in leaves treated with a freeze-thaw cycle to induce necrosis (R. Mittler and $E$. Lam, personal communication). Mittler and Lam have also identified $\mathrm{Ca}^{2+}$-dependent endonucleases that are activated during HR-associated cell death. These enzymes may be responsible for the DNA fragmentation that was seen in HR lesions of TMV-inoculated tobacco (Mittler and Lam, 1995). No nucleosomal DNA laddering was detected in this TMVinoculated tissue.

Large DNA fragments (40 to $50 \mathrm{~kb}$ ) were also detected in soybean suspension cells inoculated with an avirulent bacterium or treated with $\mathrm{H}_{2} \mathrm{O}_{2}$ (Levine et al., 1996; see also below). However, no control treatment inducing a known non-PCD type of cell death (e.g., heavy metals or freeze-thaw cycles) was reported in these experiments. The appearance of large DNA fragments in plants in which defense response pathways have been induced is consistent with the large DNA fragments seen in animal cells undergoing apoptosis. However, it remains to be seen whether these fragments are a reliable indicator of $H R$ in plants or if they are a more general feature of different types of cell death.
There are also recent reports of oligonucleosomal-sized DNA fragments accumulating in plants during response to pathogens (Ryerson and Heath, 1996; Wang et al., 1996b). Wang et al. (1996b) presented evidence for laddering during disease symptom onset in a compatible interaction involving a fungal pathogen (Alternaria alternata $\mathrm{sp} / \mathrm{ycopersici}$ ) that uses a toxin to kill cells in the host plant, tomato. DNA laddering was also detected in tomato cells treated with arachidonic acid, an elicitor of the HR, suggesting that oligonucleosomal DNA laddering can occur in an incompatible plant-pathogen interaction. However, these authors also provided evidence for DNA laddering in tomato protoplasts and leaflets after heat shock or treatment with $\mathrm{KCN}$.

Oligonucleosomal DNA laddering was shown more conclusively by Ryerson and Heath (1996), who presented evidence of DNA laddering in leaves of bean cultivars treated with avirulent (i.e., HR-inducing) isolates of bean rust. Virulent isolates of the pathogen, which do not induce the HR, did not induce detectable DNA laddering. Whether host cell death in later stages of this particular compatible interaction correlated with laddering was not addressed. Ryerson and Heath (1996) also demonstrated that $3^{\prime}-\mathrm{OH}$ labeling, presumably of the oligonucleosomal-sized DNA fragments, was limited to the host cells containing fungal haustoria. In this case, a number of other treatments (including freezing, $\mathrm{KCN}$ treatment, and $\mathrm{H}_{2} \mathrm{O}_{2}$ application) induced non-HR cell death but not DNA laddering. Evidence for $50-\mathrm{kb}$ fragments was not presented in these two studies but is presumed to have occurred as a prerequisite to the appearance of the nucleosomal ladders.

Other morphological features characteristic of apoptosis have also been reported in several host-pathogen systems. Along with the DNA laddering, Wang et al. (1996b) detected structures reminiscent of apoptotic bodies in susceptible tomato protoplasts treated with the AAL toxin. These bodies, which contain fragmented DNA, migrated to the periphery of the cells and eventually were released from the cells into the medium. The toxin from the tomato pathogen used in these studies also induced apoptosis in mammalian cells (Wang et al., 1996a). In another experimental system, soybean cells and leaves treated with avirulent but not virulent bacteria, and tobacco cells treated with the fungal peptide elicitor cryptogein, also exhibited some features of apoptotic cell death. These included condensation of the nucleus, DNA fragmentation, shrinkage of the cell, and possibly the production of apoptotic bodies in the HR lesions of treated leaves (Levine et al., 1996).

However, in an ultrastructural study addressing cell death during the HR, none of the characteristic features of apoptotic cell death was seen (Bestwick et al., 1995). Lettuce plants were inoculated with an avirulent bacterial strain that resulted in a rapid HR. Microscopic examination of the inoculation sites revealed localized alterations in the walls of cells adjacent to bacteria, both with an avirulent strain and a mutant strain unable to trigger the HR. Cellular responses specific to the avirulent isolate included mitochondrial swelling, alteration in the permeability of the plasma membrane, vacuolation of the 
cytoplasm, and collapse of the tonoplast. These results are consistent with the description of the early events in the response of tobacco leaves to inoculation with an avirulent bacterial strain (Fett and Jones, 1995) and have more in common with morphological definitions of necrotic cell death in animals than with apoptotic cell death.

Root cortical cells in soybean $r n$ mutants also exhibit morphological features of animal cell apoptosis at the ultrastructural level (i.e., nuclear blebbing, chromatin condensation at the periphery of the nucleus, and 3'-OH end labeling) before glyceollin accumulation and the induction of defense response-related group II anionic peroxidases (R. Kosslak, M. Chamberlin, R. Palmer, and B. Bowen, personal communication). These morphologies were also detected in root cap cells that are sloughed off in an example of developmentally controlled cell death (Wang et al., 1996b).

Although evidence for a type of PCD in plants with at least some functional parallels to apoptosis is mounting, evidence for common features at the molecular level is more elusive. A number of positive (e.g., ced-3 and ced-4) and negative (e.g., ced-9, bcl-2, and dad-1) regulators of cell death in animal systems have been identified (reviewed in Hengartner and Horvitz, 1994; Vaux et al., 1994; Korsmeyer, 1995; Stellar, 1995; Wyllie, 1995), but with one exception, homologous genes in plants have not been found. This could indicate that the corresponding plant sequences have diverged so much that the sequences are no longer detected as homologous, although the function may be conserved, or it may indicate that plants have evolved other means of controlling these pathways. For example, expression of $B C L-X_{L}$, a negative regulator of cell death in animals, in tobacco did not affect the HR produced in response to TMV or avirulent bacteria (R. Mittler and E. Lam, personal communication). Similarly, BCL-2 did not protect maize culture cells from the PCD induced by a calcium ionophore (M. Chamberlin, G. St. Clair, and B. Bowen, personal communication). In contrast, dad-1, identified by its ability to protect hamster cells from PCD (Nakashima et al., 1993; Sugimoto et al., 1995), is unique among known animal genes that regulate cell death in that it has homologs in plants. Expressed sequence tags with a high degree of homology with mammalian dad-1 have been identified in maize, rice, and Arabidopsis. However, it remains to be seen whether the corresponding genes perform similar functions in plants.

These sets of somewhat conflicting data need to be reconciled if one seeks a single PCD model for the HR. Alternatively, nucleosomal DNA laddering may be a function of some but not all forms of HR cell death in plants. That a toxin produced during a compatible interaction or freeze-thaw triggered cell death results in formation of $50-\mathrm{kb}$ fragments may imply that HR and nonspecific cell death share common steps in this downstream portion of the death pathway but not in the subsequent steps leading to oligonucleosomal DNA ladders. The outcome of this debate is not nearly as critical as understanding mechanistically whether these DNA fragmentation phenotypes are a requisite step for the HR, pathogen killing, or both.
Thus, comparisons of cell death in plants and animals are confusing. Different systems seem to exhibit various combinations of the features of apoptosis. Plants have likely evolved more than one way to deal with a prospective pathogen, and the differences seen may reflect the variety of different systems used. Although some host-pathogen interactions result in host cell death with many of the features of apoptosis, this may not be a universal feature of hypersensitive plant cell death. Furthermore, it may be that cells directly triggered by a pathogen to die via mechanisms featuring commonalities to apoptosis could subsequently trigger cell death in adjacent cells via another pathway. These events would be phenomenologically similar to the lesions formed after a variety of infections that have features of rapid cell death (potentially of the HR mechanism) but that also lead to diseaselike symptoms such as toxin-dependent chlorosis at their periphery. Also, the particular type of host response may be dependent on the dose of stimulus, as is known for some animal systems (Lennon et al., 1991).

\section{CELL DEATH REQUIEM}

As the genetics, cell biology, and physiology of disease resistance mechanisms continue to be unravelled, we will ultimately have answers to the questions posed in the beginning of this review regarding the cell death component of the HR. So far, it is clear that many aspects of the HR can be generated by the plant cell in the absence of pathogen (suicide, not murder). It is equally clear that many loci are involved in restricting pathogen-induced damage during incompatible interactions (such as $L L S 1, A C D 1$, and $L S D 1$ ), and it is also obvious that many loci contribute to containing pathogen growth during the onset of disease (Glazebrook et al., 1996).

We do not yet know whether HR cell death and disease symptoms are dictated by independent genetic paths. However, many of the same molecular and biochemical markers associated with the former are also observed in the latter, albeit often much later and at lower magnitudes. Thus, it could be that resistance and susceptibility (and the cell death attendant to each) are extremes of the same continuum. To date, it is apparent that in several cases, the HR can be genetically and physiologically separated from disease resistance. Whether or not this holds in general, detailed knowledge of the mechanism(s) by which plant cells die during pathogen attack will continue to be a useful tool in understanding disease resistance.

\section{ACKNOWLEDGMENTS}

We are indebted to the many scientists who communicated unpublished information and critical comments to us for inclusion in this article: Drs. Chris Lamb, Alex Levine, and Roger Pennell (Salk Institute, La 
Jolla, CA); Dierk Scheel and Thorsten Nürnberger (Institute of Plant Biochemistry, Halle, Germany); Thorsten Jabs (Rhenisch-Westfälisch Technische Hochschule, Aachen, Germany); Ben Bowen and colleagues (Pioneer Hi-Bred, Johnston, IA); Guri Johal and John Gray, (University of Missouri, Columbia); Jean Greenberg (University of Colorado, Boulder); and Ron Mittler, Eric Lam, and colleagues (Waksman Institute, Rutgers University, New Brunswick, NJ). We are also grateful to Drs. Alan Jones (University of North Carolina, Chapel Hill), John Mansfield (Wye College, Ashford, UK), Jonathan Jones and Kim Hammond-Kosack (Sainsbury Laboratory, Norwich, UK) for discussions that helped to formulate some of the ideas articulated here.

\section{REFERENCES}

Alfano, J.R., and Collmer, A. (1996). Bacterial pathogens in plants: Life up against the wall. Plant Cell 8, 1793-1807.

Auh, C.-K., and Murphy, T.M. (1995). Plasma membrane redox enzyme is involved in the synthesis of $\mathrm{O}_{2}-$ and $\mathrm{H}_{2} \mathrm{O}_{2}$ by Phytophthora elicitor-stimulated rose cells. Plant Physiol. 107, 1241-1247.

Baker, C.J., and Orlandi, E.W. (1995). Active oxygen in plant pathogenesis. Annu. Rev. Phytopathol. 33, 299-322.

Baker, C.J., Orlandi, E.W., and Mock, N.M. (1993). Harpin, an elicitor of the hypersensitive response in tobacco caused by Erwinia amylovora, elicits active oxygen production in suspension. Plant Physiol. 102, 1341-1344.

Becker, F., Buschfeld, E., Schell, J., and Bachmair, A. (1993). Altered response to viral infection by tobacco plants perturbed in ubiquitin system. Plant J. 3, 875-881.

Beffa, R.S., Hofer, R.-M., Thomas, M., and Meins, F., Jr. (1996). Decreased susceptibility to viral disease of $\beta$-1,3-glucanase-deficient plants generated by antisense transformation. Plant Cell 8, 1001-1011.

Bennetzen, J.L., Qin, M., Ingels, S., and Ellingboe, A.H. (1988). Allele-specific and Mutator-associated instability at the Rp1 diseaseresistance locus of maize. Nature 332, 369-370.

Bent, A.F. (1996). Plant disease resistance genes: Function meets structure. Plant Cell 8, 1757-1771.

Bent, A.F., Innes, R.W., Ecker, J.R., and Staskawicz, B.J. (1992). Disease development in ethylene-insensitive Arabidopsis thaliana infected with virulent and avirulent $P$ seudomonas and Xanthomonas pathogens. Mol. Plant-Microbe Interact. 5, 372-378.

Bestwick, C.S., Bennett, M.H., and Mansfield, J.W. (1995). Hrp mutant of Pseudomonas syringae pv. phaseolicola induces cell wall alterations but not membrane damage leading to the hypersensitive reaction in lettuce. Plant Physiol. 108, 503-516.

Bi, Y.-M., Kenton, P., Mur, L., Darby, R., and Draper, J. (1995). Hydrogen peroxide does not function downstream of salicylic acid in the induction of PR protein expression. Plant J. 8, 235-246.

Bowling, S.A., Guo, A., Cao, H., Gordon, A.S., Klessig, D.F., and Dong, X. (1994). A mutation in Arabidopsis that leads to constitutive expression of systemic acquired resistance. Plant Cell 6, 1845-1857.

Boyes, D.C., McDowell, J.M., and Dangl, J.L. (1996). Many roads lead to resistance. Curr. Biol. 6, 634-637.

Bradley, D., Kjellbom, P., and Lamb, C. (1992). Elicitor- and woundinduced oxidative cross-linking of a proline-rich plant cell wall protein: A novel, rapid defense response. Cell 70, 21-30.
Brisson, L.F., Tenhaken, R., and Lamb, C. (1994). Function of oxidative cross-linking of cell wall structural proteins in plant disease resistance. Plant Cell 6, 1703-1712.

Cao, H., Bowling, S.A., Gordon, A.S., and Dong, X. (1994). Characterization of an Arabidopsis mutant that is nonresponsive to inducers of systemic acquired resistance. Plant Cell 6, 1583-1592.

Century, K.S., Holub, E.B., and Staskawicz, B.J. (1995). NDR1, a locus of Arabidopsis thaliana that is required for disease resistance to both a bacterial and a fungal pathogen. Proc. Natl. Acad. Sci. USA 92, 6597-6601.

Chester, K.S. (1933). The problem of acquired physiological immunity in plants. Q. Rev. Biol. 8, 275-324.

Cohen, Y., and Kuc, J. (1981). Evaluation of systemic resistance to blue mold induced in tobacco leaves by prior stem inoculation with Peronospora tabacina. Phytopathology 71, 783-787.

Collins, R.J., Harmon, B.V., Gobe, G.C., and Kerr, J.F.R. (1992). Internucleosomal DNA cleavage should not be the sole criterion for identifying apoptosis. Int. J. Radiat. Biol. 61, 451-453.

Croft, K., Juttner, F., and Slusarenko, A. (1993). Volatile products of the lipoxygenase pathway evolved from Phaseolus vulgaris (L.) leaves inoculated with Pseudomonas syringae pv phaseolicola. Plant Physiol. 101, 13-24.

Culver, J.N., and Dawson, W.O. (1991). Tobacco mosaic virus elicitor coat protein genes produce a hypersensitive phenotype in transgenic Nicotiana sylvestris plants. Mol. Plant-Microbe Interact. 4, 458-463.

Dangl, J.L. (1995). Pièce de résistance: Novel classes of plant disease resistance genes. Cell 80, 363-366

Delaney, T., Uknes, S., Vernooij, B., Friedrich, L., Weymann, K., Negrotto, D., Gaffney, T., Gut-Rella, M., Kessman, H., Ward, E., and Ryals, J. (1994). A central role of salicylic acid in plant disease resistance. Science 266, 1247-1250.

Delaney, T.P., Friedrich, L., and Ryals, J.A. (1995). Arabidopsis signal transduction mutant defective in chemically and biologically induced disease resistance. Proc. Natl. Acad. Sci. USA 92, 6602-6606.

Dietrich, R.A., Delaney, T.P., Uknes, S.J., Ward, E.J., Ryals, J.A., and Dangl, J.L. (1994). Arabidopsis mutants simulating disease resistance response. Cell 77, 565-578.

Dixon, M.S., Jones, D.A., Keddie, J.S., Thomas, C.M., Harrison, K., and Jones, J.D.G. (1996). The tomato Cf-2 disease resistance locus comprises two functional genes encoding leucine-rich repeat proteins. Cell 84, 451-460.

Dixon, R.A., Harrison, M.J., and Lamb, C.J. (1994). Early events in the activation of plant defense responses. Annu. Rev. Phytopathol. 32, 479-501.

Doke, N. (1983). Involvement of superoxide anion generation in the hypersensitive response of potato tuber tissues to infection with an incompatible race of Phytophthora infestans and to the hyphal wall components. Physiol. Plant Pathol. 23, 345-357.

Doke, N. (1985). NADPH-dependent $\mathrm{O}_{2}^{-}$generation in membrane fractions isolated from wounded potato tubers inoculated with Phytophthora infestans. Physiol. Plant Pathol. 27, 311-322.

Doke, N., and Ohashi, Y. (1988). Involvement of an $\mathrm{O}_{2}{ }^{-}$-generating system in the induction of necrotic lesions on tobacco leaves infected with tobacco mosaic virus. Physiol. Mol. Plant Pathol. 32, 163-175. 
Dwyer, S.C., Legrendre, L., Low, P.S., and Leto, T.L. (1995). Plant and human neutrophil oxidative burst complexes contain immunologically related proteins. Biochem. Biophys. Acta 1289, 231-237.

Enyedi, A.J., Yalpani, N., Silverman, P., and Raskin, I. (1992). Signal molecules in systemic plant resistance to pathogens and pests. Cell 70, 879-886.

Fett, W.F., and Jones, S.B. (1995). Microscopy of the interaction of hrp mutants of Pseudmonas syringae pv. phaseolicola with a nonhost plant. Plant Sci. 107, 27-39.

Freialdenhoven, A., Peterhänsel, C., Kurth, J., Kreuzaler, F., and Schulze-Lefert, P. (1996). Identification of genes required for the function of non-race-specific mlo resistance to powdery mildew in barley. Plant Cell 8, 5-14.

Freytag, S., Arabatzis, N., Hahlbrock, K., and Schmelzer, E. (1994). Reversible cytoplasmic rearrangements precede cell wall apposition, hypersensitive cell death and defense-related gene activation in potato/Phytophthora infestans interactions. Planta 194, 123-135.

Gaffney, T., Friedrich, L., Vernooij, B., Negrotto, D., Nye, G., Uknes, S., Ward, E., and Ryals, J. (1993). Requirement for salicylic acid for the induction of systemic acquired resistance. Science 261, 754-756.

Glazebrook, J., Rogers, E.E., and Ausubel, F.M. (1996). Isolation of Arabidopsis mutants with enhanced disease susceptibility by direct screening. Genetics 143, 973-982.

Glazener, J.A., Orlandi, E.W., and Baker, C.J. (1996). The active oxygen response of cell suspensions to incompatible bacteria is not sufficient to cause hypersensitive cell death. Plant Physiol. 110, 759-763.

Godiard, L., Grant, M.R., Dietrich, R.A., Kiedrowski, S., and Dangl, J.L. (1994). Perception and response in plant disease resistance. Curr. Opin. Genet. Dev. 4, 662-671.

Greenberg, J.T., and Ausubel, F.M. (1993). Arabidopsis mutants compromised for the control of cellular damage during pathogenesis and aging. Plant J. 4, 327-342.

Greenberg, J.T., and Sussex, I. (1996). Programmed cell death: A way of life for plants. Proc. Natl. Acad. Sci. USA, in press.

Greenberg, J.T., Guo, A., Klessig, D.F., and Ausubel, F.M. (1994). Programmed cell death in plants: A pathogen-triggered response activated coordinately with multiple defense functions. Cell 77 , 551-564.

Groom, Q.J., Torres, M.A., Fordham-Skelton, A.P., HammondKosack, K.E., Robinson, N.J., and Jones, J.D.G. (1996). rbohA, a rice homologue of the mammalian gp91phox respiratory burst oxidase gene. Plant J. 10, 515-522.

Hahlbrock, K., Scheel, D., Logemann, E., Nurnburger, T., Parniske, M., Reinold, S., Sacks, W.R., and Schmelzer, E. (1995). Oligopeptide elicitor-mediated defense gene activation in cultured parsley cells. Proc. Natl. Acad. Sci. USA 92, 4150-4157.

Halliwell, B., and Gutteridge, J.M.C. (1989). Free Radicals in Biology and Medicine. (Oxford, UK: Clarendon Press).

Hammond-Kosack, K.E., and Jones, J.D.G. (1996). Resistance gene-dependent plant defense responses. Plant Cell 8, 1773-1791.

Hammond-Kosack, K.E., Harrison, K., and Jones, J.D.G. (1994). Developmentally regulated cell death on expression of the fungal avirulence gene Avr9 in tomato seedlings carrying the diseaseresitance Cf-9 gene. Proc. Natl. Acad. Sci. USA 91, 10445-10449.

Hammond-Kosack, K.E., Silverman, P., Raskin, I., and Jones, J.D.G. (1996). Race-specific elicitors of Cladosporium fulvum induce changes in cell morphology, and ethylene and salicylic acid synthesis, in tomato cells carrying the corresponding Cf-disease resistance gene. Plant Physiol. 110, 1381-1394.

He, S.Y., Huang, H.-C., and Collmer, A. (1993). Pseudomonas syringae pv. syringae harpin Pss: A protein that is secreted via the Hrp pathway and elicits the hypersensitive response in plants. Cell 73, 1255-1266.

Hengartner, M.O., and Horvitz, H.R. (1994). Programmed cell death in Caenorhabditis elegans. Curr. Opin. Genet. Dev. 4, 581-586.

Herbers, K., Meuwly, P., Frommer, W.B., Métraux, J.-P., and Sonnewald, U. (1996). Systemic acquired resistance mediated by the ectopic expression of invertase: Possible hexose sensing in the secretory pathway. Plant Cell 8, 793-803.

Hooker, A.L., and Russell, W.A. (1962). Inheritance of resistance to Puccinia sorghi in six maize inbred lines. Phytopathology 52, 122-128.

Hu, G., Richter, T.E., Hulbert, S.H., and Pryor, T. (1996). Disease lesion mimicry caused by mutations in the rust resistance gene rp1. Plant Cell 8, 1367-1376.

Huynh, T.V., Dahlbeck, D., and Staskawicz, B.J. (1989). Bacterial blight of soybean: Regulation of a pathogen gene determining host cultivar specificity. Science 245, 1374-1377.

Inzé, D., and Van Montagu, M. (1995). Oxidative stress in plants. Curr. Opin. Biotechnol. 3, 153-158.

Jabs, T., Dietrich, R.A., and Dangl, J.L. (1996). Initiation of runaway cell death in an Arabidopsis mutant by extracellular superoxide. Science 273, 1853-1856.

Jakobek, J.L., and Lindgren, P.B. (1993). Generalized induction of defense responses in bean is not correlated with the induction of the hypersensitive reaction. Plant Cell 5, 49-56.

Jenns, A., and Kuc, J. (1977). Localized infection with tobacco necrosis virus protects cucumber against Colletotrichum lagenarium. Physiol. Plant Pathol. 11, 207-212.

Johal, G.S., Hulbert, S.H., and Briggs, S.P. (1994a). Disease lesion mimics of maize: A model for cell death in plants. Bioessays 17, 685-692.

Johal, G.S., Lee, E.A., Close, P.S., Coe, E.H., Neuffer, M.G., and Briggs, S.P. (1994b). A tale of two mimics: Transposon mutagenesis and characterization of two disease lesion mimic mutations in maize. Maydica 39, 69-76.

Jones, A.M., and Dangl, J.L. (1996). Logjam at the Styx: Programmed cell death in plants. Trends Plant Sci. 1, 114-119.

Jones, J.D.G. (1994). Paranoid plants have their genes examined. Curr. Biol. 4, 749-751.

Kauss, H., and Jeblick, W. (1995). Pretreatment of parsley suspension cultures with salicylic acid enhances spontaneous and elicited production of $\mathrm{H}_{2} \mathrm{O}_{2}$. Plant Physiol. 108, 1171-1178.

Kauss, H., Theisinger-Hinkel, E., Mindermann, R., and Conrath, U. (1992). Dichloroisonicotinic and salicylic acid, inducers of systemic acquired resistance, enhance fungal elicitor responses in parsley cells. Plant J. 2, 655-660.

Kiyosawa, S. (1970). Inheritance of a particular sensitivity of the rice variety Sekiguchi Asahi, to pathogens and chemicals, and linkage relationships with blast resistance genes. Bull. Nat. Inst. Agric. Sci. (Jpn.) Ser. D Physiol. Genet. 21, 61-71.

Knogge, W. (1996). Fungal infection of plants. Plant Cell 8, 1711-1722.

Korsmeyer, S.J. (1995). Regulators of cell death. Trends Genet. 11, 101-105. 
Kosslak, R.M., Dieter, J.R., Ruff, R.L., Chamberlin, M.A., Bowen, B.A., and Palmer, R.G. (1996). Tolerance to root-borne infection by Phytophthora sojae in three allelic necrotic-root mutants in soybean. J. Hered., in press.

Kuć, J. (1987). Plant immunization and its applicability for disease control. In Innovative Approaches to Plant Disease Control, I. Chet, ed (New York: John Wiley and Sons), pp. 255-275.

Langford, A.N. (1948). Autogenous necrosis in tomatoes immune from Cladosporium fulvum Cooke. Can. J. Res. 26, 35-64.

Lawton, K.A., Potter, S.L., Uknes, S., and Ryals, J. (1994). Acquired resistance signal transduction in Arabidopsis is ethylene independent. Plant Cell 6, 581-588.

Lawton, K., Weymann, K., Friedrich, L., Vernooij, B., Uknes, S., and Ryals, J. (1995). Systemic acquired resistance in Arabidopsis requires salicylic acid but not ethylene. Mol. Plant-Microbe Interact. 8, 863-870.

Legendre, L., Reuter, S., Heinstein, P.F., and Low, P.S. (1993). Characterization of the oligogalacturonide-induced oxidative burst in cultured soybean (Glycine max) cells. Plant Physiol. 102, 233-240.

Lennon, S.V., Martin, S.J., and Cotter, T.G. (1991). Dose-dependent induction of apoptosis in human tumor cell lines by widely diverging stimuli. Cell Prolif. 24, 203-214.

Léon, J., Lawton, M.A., and Raskin, I. (1995). Hydrogen peroxide stimulates salicylic acid biosynthesis in tobacco. Plant Physiol. 108, 1673-1678.

Levine, A., Tenhaken, R., Dixon, R., and Lamb, C.J. (1994). $\mathrm{H}_{2} \mathrm{O}_{2}$ from the oxidative burst orchestrates the plant hypersensitive disease resistance response. Cell 79, 583-593.

Levine, A., Pennell, R., Palmer, R., and Lamb, C.J. (1996). Calciummediated apoptosis in a plant hypersensitive response. Curr. Biol. $6,427-437$.

Low, P.S., and Merida, J.R. (1996). The oxidative burst in plant defense: Function and signal transduction. Physiol. Plant. 96, 533-542.

Marchetti, M.A., Bollich, C.N., and Uecker, F.A. (1983). Spontaneous occurence of the Sekiguchi lesion in two American rice lines: Its induction, inheritance, and utilization. Phytopathology 73, 603-606.

Martin, G.B., Brommonschenkel, S.H., Chunwongse, J., Frary, A., Ganal, M.W., Splvey, R., Wu, T., Earle, E.D., and Tanksiey, S.D. (1993). Map-based cloning of a protein kinase gene conferring disease resistance in tomato. Science 262, 1432-1436.

Mauch-Mani, B., and Slusarenko, A.J. (1996). Production of salicylic acid precursors is a major function of phenylalanine-ammonia lyase in the resistance of Arabidopsis to Peronospora parasitica. Plant Cell 8, 203-212.

May, M.J., Hammond-Kosack, K.E., and Jones, J.D.G. (1996). Involvement of reactive oxygen species, glutathione metabolism and lipid peroxidation in the Cf-gene-dependent defense response of tomato cotyledons induced by race-specific elicitors of Cladosporium fulvum. Plant Physiol. 110, 1367-1380.

Mehdy, M.C. (1994). Active oxygen species in plant defense against pathogens. Plant Physiol. 105, 467-472.

Mittler, R., and Lam, E. (1995). Identification, characterization, and purification of a tobacco endonuclease activity induced upon hypersensitive response cell death. Plant Cell 7, 1951-1962.

Mittler, R., Shulaev, V., and Lam, E. (1995). Coordinated activation of programmed cell death and defense mechanisms in transgenic tobacco plants expressing a bacterial proton pump. Plant Cell 7 29-42.

Mur, L.A.J., Naylor, G., Warner, S.A.J., Sugars, J.M., White, R.F, and Draper, J. (1996). Salicylic acid potentiates defence gene expression in tissue exhibiting acquired resistance to pathogen attack. Plant J. 9, 559-572.

Murphy, T.M., and Auh, C.-K. (1996). The superoxide synthases of plasma membrane preparations from cultured rose cells. Plant Physiol. 110, 621-629.

Nakashima, T., Sekiguchi, T., Kuraoka, A., Fukushima, K., Shibata, Y., Komiyama, S., and Nishimoto, T. (1993). Molecular cloning of a human cDNA encoding a novel protein, DAD1, whose defect causes apoptotic cell death in Hamster BHK21 cells. Mol. Cell. Biol. 13, 6367-6374.

Neuenschwander, U., Vernooij, B., Friedrich, L., Uknes, S., Kessman, H., and Ryals, J. (1995). Is hydrogen peroxide a second messenger of salicylic acid in systemic acquired resistance? Plant J. 8, 227-234.

Nürnberger, T., Nennstiel, D., Jabs, T., Sacks, W.R., Hahlbrock, K., and Scheel, D. (1994). High-affinity binding of a fungal oligopeptide elicitor to parsley plasma membranes triggers multiple defense responses. Cell 78, 449-460.

Peng, M., and Kuć, J. (1992). Peroxidase-generated hydrogen peroxide as a source of antifungal activity in vitro and on tobacco leaf disks. Phytopathology 82, 696-699.

Pryor, A. (1987a). The origin and stucture of fungal disease resistance genes. Trends Genet. 3, 157-161.

Pryor, T.P. (1987b). Stability of alleles at Rp (resistance to Puccinia sorghi). Maize Genet. Newsi. 61, 37-38.

Pryor, T.P., and Ellis, J. (1993). The genetic complexity of fungal resistance genes in plants. Adv. Plant Pathol. 10, 281-307.

Qin, X.-F., Holuigue, L., Horvath, D.M., and Chua, N.-H. (1994). Immediate early transcription activation by salicylic acid via the cauliflower mosaic virus as-1 element. Plant Cell 6, 863-874.

Raff, M. (1992). Social controls on cell survival and cell death. Nature 356, 397-400.

Raff, M.C., Barres, B.A., Burne, J.F., Coles, H.S., Ishizaki, Y., and Jacobson, M.D. (1993). Programmed cell death and the control of cell survival: Lessons from the nervous system. Science 262, 695-700.

Richter, T.E., Pryor, T.J., Bennetzen, J.B., and Hulbert, S.H. (1995). New rust resistance specificities associated with recombination in the Rp1 complex in maize. Genetics 141, 373-381.

Ryals, J., Uknes, S., and Ward, E. (1994). Systemic acquired resistance. Plant Physiol. 104, 1109-1112.

Ryals, J.A., Neuenschwander, U.H., Willits, M.G., Molina, A., Steiner, H.Y., and Hunt, M.D. (1996). Systemic acquired resistance. Plant Cell 8, 1809-1819.

Ryerson, D.E., and Heath, M.C. (1996). Cleavage of nuclear DNA into oligonucleosomal fragments during cell death induced by fungal infection or by abiotic treatments. Plant Cell 8, 393-402.

Sano, H., Seo, S., Orudgev, E., Yousseflan, S., Ishizuka, K., and Ohashi, Y. (1994). Expression of the gene for a small GTP binding protein in transgenic tobacco elevates endogenous cytokinin levels, abnormally induces salicylic acid in response to wounding and increases resistance to tobacco mosaic virus infection. Proc. Natl. Acad. Sci. USA 91, 10556-10560. 
Schmelzer, E., Krüger-Lebus, S., and Hahlbrock, K. (1989). Temporal and spatial patterns of gene expression around sites of attempted fungal infection in parsley leaves. Plant Cell 1, 993-1001.

Schwacke, R., and Hager, A. (1992). Fungal elicitors induce a transient release of active oxygen species from cultured spruce cells that is dependent on $\mathrm{Ca}^{2+}$ and protein-kinase activities. Planta 187, 136-141.

Segal, A.W., and Abo, A. (1993). The biochemical basis of the NADPH oxidase of phagocytes. Trends Biochem. Sci. 18, 48-52.

Somssich, I.E., Schmelzer, E., Kawalleck, P., and Hahlbrock, K. (1988). Gene structure and in situ transcript localization of pathogenesis-related protein 1 in parsley. Mol. Gen. Genet. 213, 93-98.

Staskawicz, B.J., Ausubel, F.M., Baker, B.J., Ellis, J., and Jones, J.D.G. (1995). Molecular genetics of plant disease resistance. Science 268, 661-667.

Stellar, H. (1995). Mechanisms and genes of cellular suicide. Science 267, 1445-1499.

Strittmatter, G., Janssens, J., Opsomer, C., and Botterman, J. (1995). Inhibition of fungal disease development in plants by controlled cell death. Bio/Technology 13, 1085-1089.

Sudupak, M., Bennetzen, J.L., and Hulbert, S.H. (1993). Unequal exchange and meiotic instability of disease-resistance genes in the Rp1 region of maize. Genetics 133, 119-125.

Sugimoto, A., Hozak, R.R., Nakashima, T., Nishimoto, T., and Rothman, J.H. (1995). dad-1, an endogenou's programmed cell death suppressor in Caenorhabditis elegans and vertebrates. EMBO J. 14, 4434-4441.

Takahashi, H., Goto, N., and Ehara, Y. (1994). Hypersensitive response in cucumber mosaic-virus infected Arabidopsis thaliana. Plant J. 6, 369-378.

Tavernier, E., Wendehenne, D., Blein, J.P., and Pugin, A. (1995). Involvement of free calcium in action of cryptogein, a proteinaceous elicitor of hypersensitive response in tobacco cells. Plant Physiol. 109, 1025-1031.

Tenhaken, R., Levine, A., Brisson, L.F., Dixon, R.A., and Lamb, C.J. (1995). Function of the oxidative burst in hypersensitive disease resistance. Proc. Natl. Acad. Sci. USA 92, 4158-4163.

Uknes, S., Dincher, S., Friedrich, L., Negrotto, D., Williams, S., Thompson-Taylor, H., Potter, S., Ward, E., and Ryals, J. (1993). Regulation of pathogenesis-related protein 1-a gene expression in tobacco. Plant Cell 5, 159-169.

Ullstrup, A.J., and Troyer, A.F. (1967). A lethal leaf spot of maize. Phytopathology 57, 1282-1283.

Van den Ackerveken, G.F.J.M., Van Kan, J.A.L., and De Wit, P.J.G.M. (1992). Molecular analysis of the avirulence gene avr9 of the fungal tomato pathogen Cladosporium fulvum fully supports the gene-forgene hypothesis. Plant J. 2, 359-366.

Van Kan, J.A.L., Van den Ackerveken, G.F.J.M., and De Wit, P.J.G.M. (1991). Cloning and characterization of cDNA of avirulence gene avr9 of the fungal pathogen Cladosporium fulvum, causal agent of tomato leaf mold. Mol. Plant-Microbe Interact. 4, 52-59.

Vaux, D., Haecker, G., and Strasser, A. (1994). An evolutionary perspective on apoptosis. Cell 76, 777-779.

Vera-Estrella, R., Barkla, B.J., Higgins, V.J., and Blumwald, E. (1994). Plant defense response to fungal pathogens: Activation of host-plasma membrane $\mathrm{H}^{+}$-ATPase by elicitor-induced enzyme dephosphorylation. Plant Physiol. 104, 209-215.

Walbot, V., Hoisington, D.A., and Neuffer, M.G. (1983). Disease lesion mimics in maize. In Genetic Engineering of Plants, T. Kosuge and C. Meredith, eds (New York: Plenum Publishing), pp. 431-442.

Wang, H., Jones, C., Ciacci-Zanella, J., Holt, T., Gilchrist, D.G., and Dickman, M.B. (1996a). Fumonisins and AAl toxins: Sphinganine analog mycotoxins induce apoptosis in monkey kidney cells. Proc. Natl. Acad. Sci. USA 93, 3461-3465.

Wang, H., Li, J., Bostock, R.M., and Gilchrist, D.G. (1996b). Apoptosis: A functional paradigm for programmed plant cell death induced by a host-selective phytotoxin and invoked during development. Plant Cell 8, 375-391.

Weyman, K., Hunt, M., Uknes, S., Neuenschwander, U., Lawton, K., Steiner, H.Y., and Ryals, J. (1995). Suppression and restoration of lesion formation in Arabidopsis /sd mutants. Plant Cell 7, 2013-2022.

Wolter, M., Hollricher, K., Salamini, F., and Schulze-Lefert, P. (1993). The $m$ lo resistance alleles to powdery mildew infection in barley trigger a developmentally controlled defence mimic phenotype. Mol. Gen. Genet. 239, 122-128.

Wu, G., Shortt, B.J., Lawrence, E.B., Levine, E.B., Fitzsimmons, K.C., and Shah, D.M. (1995). Disease resistance conferred by expression of a gene encoding $\mathrm{H}_{2} \mathrm{O}_{2}$-generating glucose oxidase in transgenic potato plants. Plant Cell 7, 1357-1368.

Wyllie, A.H. (1995). The genetic regulation of apoptosis. Curr. Opin. Genet. Dev. 5, 97-104.

Wyllie, A.H., Kerr, J.F.R., and Curries, A.R. (1980). Cell death: The significance of apoptosis. Int. Rev. Cytol. 68, 251-306.

Xing, T., Higgins, V.J., and Blumwald, E. (1996). Regulation of plant defense response to fungal pathogens: Two types of protein kinases in the reversible phosphorylation of the host plasma membrane $\mathrm{H}^{+}$ATPase. Plant Cell 8, 555-564.

Zhou, J., Loh, Y., Bressan, R.A., and Martin, G.B. (1995). The tomato gene Pti encodes a serine/threonine kinase that is phosphorylated by Pto and is involved in the hypersensitive response. Cell 83, 925-935. 